\title{
An outbreak of illness in poultry and humans in 16th century Indonesia
}

\author{
Sanjaya N Senanayake and Brett C Baker
}

\begin{abstract}
An obscure Portuguese document from 16th century Indonesia describes an illness that destroyed poultry before devastating the human population of the region. The cause of the illness remains unresolved; it may have been infectious or non-infectious. Isolation of the region because of trading practices probably prevented spread of the illness, reinforcing the value of quarantine or isolation as a public health measure
\end{abstract}

$\mathrm{T}$ he following extract comes from an unsigned treatise written by António Galvão, captain from 1536 to 1539 of the Portuguese fortress on the island of Ternate in the Maluku archipelago, in what is now Indonesia (Box):

At the end of April 1539 there appeared in Ternate and throughout this region a star in the west, with many enormous rays like a natural torch, similar to the one that was seen in Portugal when the earth shook. It lasted throughout May and June. With the south winds came this sickness to Bacan; before long it spread throughout all the islands beginning in the chickens. Because it happened one morning that more than 50 or 60 chickens belonging to António Galvão which had been growing healthy and fat were found dead; and afterward more than 110 of his people, both servants and slaves, fell ill, not one being spared and the more part dying on him, not counting the Portuguese and their children; and this evil was so common throughout all the land that they could not bury them, and the sea was full of the dead, and many places were depopulated, and thus they found themselves in visions at night for the men were amazed, saying that they had never before seen such a thing, nor had they heard of it from their ancestors [translation by Brett Baker]. ${ }^{1}$

Although from ancient times it was traditional for authors to begin the description of any epidemic with the death of birds, ${ }^{2}$ we believe that Galvão's description was a true reflection of the events rather than a stylistic convention. Galvão made no mention of bird deaths when describing "an illness like the plague" that occurred 5 years earlier, ${ }^{1}$ therefore, his description of dying chickens in 1539 is likely to truly reflect what happened.

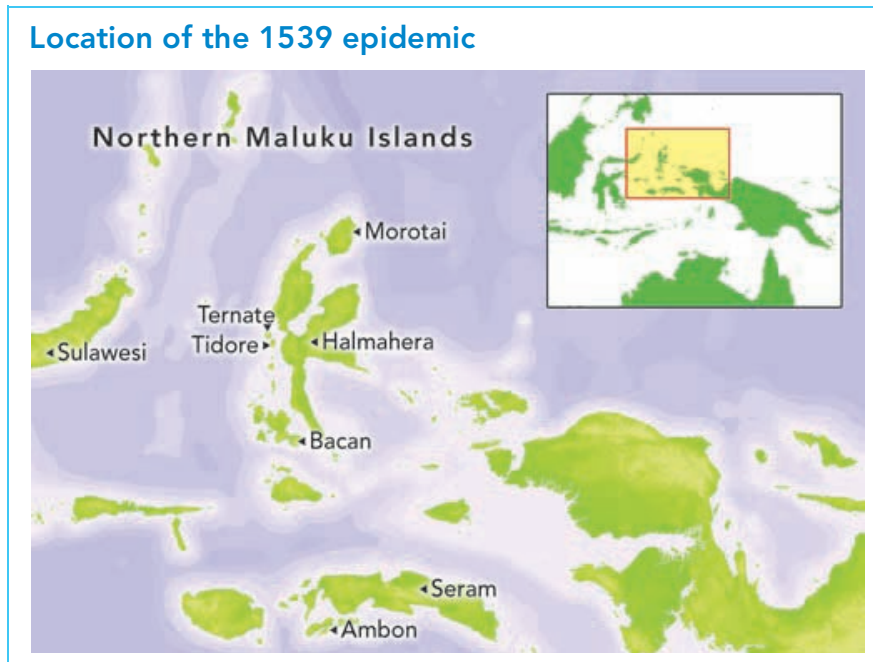

The northern islands of the Maluku archipelago in Indonesia.

\section{The 1539 epidemic}

It appears that a disease rapidly destroyed a group of 60 healthy chickens and was followed soon after by a disease of similar lethality in humans, affecting the indigenous population, slaves and the Portuguese. The striking features of this outbreak are its rapidity, severity, probably its mortality rate (although this cannot be determined) and the fact that, as it spread throughout the archipelago, it always seems to have been preceded on each island by poultry deaths. Galvão states that whole regions were depopulated. However, he may have exaggerated this. Only 7 years later, Europeans commented repeatedly on the high populations they found there, describing Ambon as "densely populated". 3 Still, it seems that the illness killed large numbers of people throughout the islands over a relatively short period. Galvão and the indigenous population did not recognise the illness, although devastating epidemics of unspecified diseases "raged through the islands every 7 or 8 years". ${ }^{4}$ The possible causes could be infectious or non-infectious.

\section{Possible infectious causes}

\section{Infections in chickens and humans}

It seems unlikely that two separate and lethal infections devastated chickens and humans almost simultaneously; therefore, a single responsible agent is more probable. Newcastle disease can kill chickens rapidly but does not cause disease in humans. ${ }^{5}$ Psittacosis can infect domestic poultry ${ }^{6}$ and then humans; however, the rapidity and lethality of the disease in 1539 in both chickens and humans is not typical of psittacosis. Anthrax is a devastating zoonosis most typically associated with herbivores. Infection of birds with anthrax is usually asymptomatic and is detected by spores shed in faeces. ${ }^{7}$ Chickens, especially, seem resistant to the disease. $^{8}$

Could avian influenza have caused the 1539 outbreak? In modern times, the $\mathrm{H} 5 \mathrm{~N} 1$ strain of avian influenza affects birds and humans, with human-to-human transmission considered to be very rare. In the current climate, one would have to consider avian influenza as a differential diagnosis for an infection targeting both domestic poultry and humans. Few zoonoses other than H5N1 influenza kill both.

Features of the 1539 outbreak have some similarity to avian influenza of the 21st century. The infection appeared to be an emerging infectious disease, not seen before by the indigenous people or the Portuguese. Also, throughout the islands, the illness seemed to affect poultry before affecting humans, supporting the idea of poultry-to-human transmission.

However, there are strong arguments against avian influenza being responsible for the 1539 outbreak. First, the large number of human casualties is in direct contrast to the situation in the 21st 
century. In today's $\mathrm{H} 5 \mathrm{Nl}$ outbreaks, human death rates are low, despite the exposure of large populations to chickens. ${ }^{9}$ This may be attributable to the $\mathrm{H} 5 \mathrm{Nl}$ virus binding only to galactose receptors in the lower respiratory tract, unlike human influenza viruses, which can bind to galactose receptors in the upper respiratory tract. ${ }^{10}$ Therefore, if avian influenza was the cause of the 16th century epidemic, the degree of human devastation described is surprising, even if Galvão exaggerated the situation. An avian influenza virus capable of human-to-human transmission might explain so many human deaths, but a mutation rapid enough to allow this is questionable. Also, H5N1 influenza in humans has a distinct clinical syndrome of focal respiratory symptoms often accompanied by diarrhoea, ${ }^{9}$ yet Galvão did not describe focal features of the 1539 outbreak. One could attribute this to a failure to record the symptoms for one reason or another, but this seems not to have been the case. The treatise elsewhere is filled with details and elaborate descriptions by Galvão, including careful depictions of the clinical features of other epidemics and illnesses. ${ }^{1}$ Therefore, it is more likely that the 1539 illness truly lacked obvious focal clinical features, possibly because of its rapid and severe course, but this would certainly make avian influenza far less likely as a diagnosis.

\section{The role of the monsoon}

Although the specific organism cannot be pinned down, the way in which the illness appeared to spread through this group of islands but not outside it also supports an infectious aetiology if the trading practices of the region are studied.

Strong monsoonal patterns strictly regulated the periods of external contact. At the time of year during which the outbreak occurred, there would have been trading only among the islands but not outside them. Generally speaking, sailing vessels from outside the region could arrive in the archipelago only twice each year during rather narrow windows of time. Most ships approached via the Java and Banda Seas, arriving in the southern part of the archipelago about mid February. Those approaching from the north would arrive around the end of October.

Regardless of when or by which route they had arrived, all sailing vessels had to depart from the Maluku archipelago via the southern route with the arrival of the south-east monsoon, about the middle of May. ${ }^{11}$ This monsoon is the "south winds" identified by Galvão as having marked the advent of the illness in Bacan. Consequently, the outbreak would have begun just as external trading vessels were departing from the island of Ambon about $350 \mathrm{~km}$ to the south, and it would be more than 5 months before the first outside ship could return to Maluku, presumably after the infection had run its course.

At the same time, traffic among the islands in the Maluku region would have continued without interruption. This was possible because korakoras and other native craft could be rowed in shallow, reef-infested seas regardless of the prevailing winds. Constant inter-island trade was necessary because so many of the spice-producing islands depended on imported foodstuffs. Bacan, where this illness was first observed, produced no food of its own and therefore relied entirely on supplies brought in from other islands, and Ternate was in almost the same situation. ${ }^{4}$

These inter-island food shipments would have included chickens. ${ }^{12}$ Chickens were imported from a handful of fertile areas within the Maluku region rather than raised locally; ${ }^{13-15}$ therefore, local inter-island trade in chickens would have been sufficient for an infection carried by fowl to "spread through all the islands".

\section{Possible non-infectious causes}

Causes of the illness other than infection could include environmental agents, especially foodborne or gaseous substances.

Claviceps purpurea is a fungus that contaminates rye-based foods primarily, resulting in outbreaks of epidemic ergotism with mortality rates of 10\%-20\%. Epidemic ergotism has been well documented from medieval times, ${ }^{16}$ so its distinct clinical syndromes (limb gangrene or recurrent abnormal posturing) would have been recognised and recorded by Galvão.

In Lake Nyos, Cameroon, in 1986, 1700 people and 3000 cattle mysteriously and suddenly died. Eventually, the culprit was found to be the massive release of carbon dioxide from crater lakes. ${ }^{17}$ It is unlikely, though, that any toxin came from the "star in the west" that Galvão described. Astronomical records confirm that a comet was visible in the sky in May 1539, indicating that Galvão's star was probably a comet in space rather than a meteorite entering the atmosphere bringing a deadly toxin. ${ }^{18,19}$ Yet, the most compelling argument against a foodborne or gaseous agent is Galvão's observation that chickens were consistently affected before humans, not just in Bacan, but in all the islands of the Maluku region. ${ }^{1}$ A zoonosis seems more plausible.

\section{Lessons for modern-day quarantine}

Although the 1539 outbreak was probably not avian influenza, it is surprising that, given the current avian $\mathrm{H} 5 \mathrm{Nl}$ pandemic, a passage about a devastating illness in poultry and humans from the 16th century has not been discussed recently. Galvão's treatise has been available in published form with a parallel English translation since 1971. As part of the Jesuit Historical Institute's Sources and studies for the history of the Jesuits series, it has likely reached a narrow and rather specialised audience, one that, until recently at least, may have skipped over the importance of an illness that appears to have affected both chickens and humans.

In conclusion, the devastating illness occurring in north-east Indonesia in the 16th century, affecting first chickens and then humans, is consistent with a zoonosis. The 16th century outbreak probably failed to spread because of the isolation of the islands from the rest of the world through climate-determined trading patterns. This reinforces the value of (even unintentional) quarantine or isolation as a public health measure. Given the ease of global movement of people, animals and cargo in the modern era, its enforcement will now be a far greater challenge.

\section{Competing interests}

None identified.

\section{Author details}

Sanjaya N Senanayake, BSc(Med), FRACP, MAppEpi, Staff Specialist in Infectious Diseases ${ }^{1}$

Brett C Baker, MA, PhD Student ${ }^{2}$

1 Department of Microbiology, Canberra Hospital, Canberra, ACT.

2 Research School of Pacific and Asian Studies, Australian National University, Canberra, ACT.

Correspondence: sanjaya.senanayake@act.gov.au 


\section{References}

1 Jacobs $H$, editor. A treatise on the Moluccas (c1544), probably the preliminary version of António Galvão's lost história das Molucas. Sources and studies for the history of the Jesuits. Vol. 3. 1st ed. Rome: St Louis, 1971: 178-180.

2 Morens D, Littman R. Epidemiology of the plague of Athens. Trans Am Philol Assoc 1992; 122: 271-304.

3 Fr Francisco Xavier SJ to the Jesuits in Europe. Ambon, May 10, 1546. In: Jacobs H, editor. Documenta Malucensia. 1st ed. Rome: Jesuit Historical Institute, 1974-1984: 7.

4 Meilink-Roelofsz MAP. Asian trade and European influence in the Indonesian archipelago between 1500 and about 1630. The Hague: Martinus Nij-hoff, 1962: 216.

5 Wilson TM, Gregg DA, King DJ, et al. Agroterrorism, biological crimes, and biowarfare targeting animal agriculture. The clinical, pathologic, diagnostic, and epidemiologic features of some important animal diseases. Clin Lab Med 2001; 21: 549-591.

6 Van Loock M, Geens T, De Smit L, et al. Key role of Chlamydophila psittaci on Belgian turkey farms in association with other respiratory pathogens. Vet Microbiol 2005; 107: 91-101.

7 Saggese MD, Noseda RP, Uhart MM, et al. First detection of Bacillus anthracis in feces of free-ranging raptors from central Argentina. J Wildl Dis 2007; 43: 136-141.

8 Clark F. Anthrax on the poultry farm. Avian Advice 2001; 3(4): 6-7.

9 Beigel JH, Farrar J, Han AM, et al. Avian influenza A (H5N1) infection in humans. N Engl J Med 2005; 353: 1374-1385.
10 Normile D. Avian influenza. Studies suggest why few humans catch the H5N1 virus. Science 2006; 311: 1692.

11 General introduction. In: Jacobs H, editor. Documenta Malucensia. 1st ed. Rome: Jesuit Historical Institute, 1974: 8*-9*.

12 Carta de Leonel de Lima a El-Rei. Malaca, 8 de Novembro de 1527. In: de Sa A, editor. Documentação para a história das missões do padroado Português do Oriente: Insulíndia. Lisbon, Portugal: Agencia Geral do Ultramar, 1954: 220.

$13 \mathrm{Fr}$ Antonio Marta, Superior, to Fr Claudio Acquaviva, General, Rome. Ambon, April 15, 1592. Via México. In: Jacobs H, editor. Documenta Malucensia. 1st ed. Rome: Jesuit Historical Institute, 1980: 325.

14 Fr Francisco Vieira SJ to the Jesuits in Portugal. Ternate, March 9 1559. In: Jacobs H, editor. Documenta Malucensia. 1st ed. Rome: Jesuit Historical Institute, 1974.

$15 \mathrm{Fr}$ Antonio Marta, Visitor of Maluku, to Fr Mario Beringucci SJ, Italy. Ambon, May 30, 1587. In: Jacobs H, editor. Documenta Malucensia. 1st ed. Rome: Jesuit Historical Institute, 1980: 200.

16 Eadie MJ. Convulsive ergotism: epidemics of the serotonin syndrome? Lancet Neurol 2003; 2: 429-434.

17 Baxter PJ, Kapila M, Mfonfu D. Lake Nyos disaster, Cameroon, 1986: the medical effects of large scale emission of carbon dioxide? BMJ 1989; 298: 1437-1441.

18 Kokott W. The comet of 1533. J Hist Astron 1981; 12: 95-112.

19 Kronk GW. 16th century comet orbits. http://cometography.com/orbits_ 16th.html (accessed Oct 2007).

(Received 4 Jun 2007, accepted 15 Oct 2007) 